\title{
A historical survey and critical evaluation concerning discipleship in the fourth gospel
}

D G van der Merwe

\section{ABSTRACT}

\begin{abstract}
A historical survey and critical evaluation concerning discipleship in the Fourth Gospel
\end{abstract}

The historical survey about discipleship in the Fourth Gospel indicates that the literature of the second half of this century was sketchy about this theme. Up till 1972 a thematic-theological approach highlighted some characteristics of discipleship as they appeared in all four gospels. The study of Jimenez (1972) was the first substantial approach to research about discipleship in the Fourth Gospel and caused a paradigm shift to restrict his study to only the Fourth Gospel. During the 80's the interest about this theme increased, due to Rudolph Bultmann. After Bultmann more attention was paid to the situation and circumstances of the audience which contribute to a greater interest on discipleship and ecclesiology in the Fourth Gospel. Although no constant current influence on discipleship has been observed, most scholars are unanimous that the focal point of discipleship lies in the "Last Discourse".

Discipleship is one of the many themes in the Fourth Gospel and contributes to the understanding of the purpose and message of the Fourth Gospel. The question is whether this theme received the substantial attention it should receive. This survey will indicate how the literature of the second half of this century has contributed to the understanding of discipleship in the Fourth Gospel. The literature consulted is ordered and handled under the following categories: bibliographies, articles, monographs, commentaries, theologies, theological dictionaries and encyclopedias.

\section{REVIEW OF LITERATURE}

\subsection{Bibliographies:}

The classified bibliographies of literature on the Fourth Gospel do not include a category for the theme of discipleship. This is surprising in the light of the fact that $\mu \alpha \theta \eta \tau \grave{\eta} \varsigma$ occurs 78 times in the Gospel and is more 
prominent than most of the words on which major studies have been done. The closest these bibliographies ${ }^{1}$ come to offering literature which bears directly on discipleship are some articles and a few monographs about certain aspects of discipleship.

\subsection{Articles ${ }^{2}$ :}

The concept of discipleship as a specific category in the four Gospels first appeared in the 1950 ' $\mathrm{s}^{3}$. Schweizer (1955) was the first to examine Johannine discipleship ${ }^{4}$. The emphasis in the Fourth Gospel, according to him, is on "nachfolgen" $(1: 37 ; 18: 12)$ which is itself a gift of grace. He notes that the initiative for discipleship lies with Jesus, that the disciples are called to a service of witness and that the disciples share the life and destiny of Jesus. Unfortunately Schweizer places too much emphasis on the "new development" the Fourth Evangelist gave to discipleship as the way to divine glory and exaltation.

Discipleship continued as a theme in the 1960's. The contributions on discipleship in this decade did not differentiate between or respect the individuality of each Gospel ${ }^{5}$. Since the seventies some major contributions to the topic have been made and they represent a wide variety of approaches:

Rigaux is the earliest representative of the 1970's approach to discipleship in the Fourth Gospel ${ }^{6}$. His method was to examine certain terms by noting their use in $L X X$ and New Testament literature and their development in the Johannine text. Rigaux chose four terms to designate the relationship of Jesus with the Father to characterize the community of disciples: $\delta \hat{o} \xi \alpha, \dot{\alpha} \gamma \iota \dot{\alpha} \zeta \omega, \dot{\varepsilon} \nu$, T $\varepsilon \lambda \varepsilon \iota \varsigma \varsigma$. Culpepper ${ }^{7}$ built on this foundation and refined the Johannine school hypothesis. The community as a fellowship of disciples is engaged in learning, obeying, remembering and studying the traditions about Jesus.

Schnackenburg in "Exkurz" 17 of his commentary on the Fourth Gospel ${ }^{8}$ gives a brief survey of the presence of the disciples in the first major division of the Gospel. According to Schnackenburg they are introduced into these Johannine texts quite deliberately. He came to the conclusion that for the Fourth Evangelist the circle of the disciples had a definite theological meaning in Jesus' work and activity on earth ${ }^{9}$. For him the disciples are representatives of the believers whom Jesus gained through his words and works, of the later community in contrast to the unbelieving Jews and of the later believers in their inadequate faith. This process is in accordance with the Fourth Evangelist's intentions as he regards the group of the disciples at the time of Jesus himself. For him the significance of the disciples existed wholly in terms of believing. 
De Jonge (1977), two years later ${ }^{10}$, develops discipleship in the Fourth Gospel under five headings: (i) Regarding the purpose of the Fourth Gospel he concludes that it is "primarily if not exclusively a book of the (Johannine) church". (ii) The mission of the disciples is to act as Jesus' representatives and thus as God's representatives on earth, over against the hostile world (17:18). (iii) In this section, dealing with chapters 13-17 and related passages, he sees the Spirit as the "life-giving power of Jesus' word operating to those who believe in Jesus as the unique Son of God". (iv) Under "the true nature of discipleship" he develops the concept of the disciples as those who "follow", "remain", and "come and see". He argues that the disciples are portrayed as models for future believers in both their acceptance and misunderstanding of Jesus' word. (v) The last section indicates that in the final analysis a "divine initiative" underlies and is manifested in the human positive reaction. The study of De Jonge is exemplary in its balanced handling of both the disciples and discipleship in the Fourth Gospel.

In 1980 Siker-Gieseler made his contribution ${ }^{11}$. His approach was to discern the prominent nuances of discipleship and to draw attention to the literary qualities of the theme rather than its historical development. According to him disciples and discipleship in the Fourth Gospel comprise one theme, which received a twofold nuance in the final form of the Gospel. He makes a clear distinction between the familiar disciples who historically accompanied Jesus and examples of discipleship portrayed by individual characters who encountered Jesus in isolated situations or scenes. He stated that each of the two nuances helps to interpret the other; both are necessary for a full understanding of the topic in the Fourth Gospel. Finally the two nuances are blended together in the Fourth Evangelist's portrayal of the Beloved Disciple who then functions as the paradigm of discipleship ${ }^{12}$. The main critique on this paper is that SikerGieseler treats the disciples only on the level of historical characters. Nowhere are they introduced as part of discipleship; they are reduced to chapters 13-17 where they are taught by Jesus. He never refers to the other characters (Nicodemus, Lazarus, etc) ${ }^{13}$ in the Fourth Gospel as part of discipleship.

In the same year (1980) Vellanickal14 wrote his paper. He concentrates on 1:35-42 to try to indicate the essential notes of discipleship as the Fourth Gospel perceives it. He discusses the relation of "Discipleship as a deepening experience with Christ". A disciple is one who, living with Jesus, gradually obtains a deeper and deeper insight into the person of Jesus and shares this experience with others. According to 
him there are three "conditions" of discipleship: (1) remaining in the Word (Jn 8:31-32), (2) hating one's life (12:25), and (3) serving Jesus (12:26). "Love" is the keynote of discipleship (13:35). His conclusion is that discipleship is an advanced stage in the life of faith resulting from a constant and dynamic indwelling presence of Jesus' words in his disciples. While reading this article one may query whether the author has not too hastily come to some opinions which favour his viewpoint? On theological grounds one must ask whether the text really supports his conclusions.

Four years later (1984), Brown ${ }^{15}$, very briefly referred to the fact that the term "apostle" is not found in the Johannine writings. Although the sending forth of Jesus is an important theme and fundamental to apostleship in the Fourth Gospel, it is not apostleship that constitutes prime dignity in Johannine ecclesiology. According to Brown the Fourth Gospel emphasizes discipleship, a status that all Christians enjoy. Within that status dignity is conferred by the love of Jesus. Because discipleship is all important, offices, charisms and other distinctions do not feature. Church offices and apostleship are, when compared with discipleship of less importance because for the evangelist discipleship is literally a question of (eternal) life and death. Within discipleship, there are no second-class christians - the love of Jesus is the only prerequisite. Although Brown admitted that the Fourth Gospel emphasizes discipleship he never developed this theme.

In 1985 Segovia $^{16}$ wrote his article about discipleship in the Fourth Gospel. Influenced by Mark R Tannehill Segovia studied the characterization of Jesus' disciples in the Fourth Gospel as a way of probing further the concept of discipleship present in the Gospel and the community situation which it reflects and presupposes. To reach the above objective he forgoes detailed discussion of individual scenes and concentrates instead on the overall development of the narrative as a whole. He attempts to trace the overall development of the disciples in the narrative according to the original sequence of the narrative. Hereafter he examines the main aspects of discipleship - that is the central themes of the disciples' characterization in the narrative - in terms of the Sitz im Leben they reflect and presuppose in the history of the Johannine community. Segovia maintains that he confirms, refines and sharpens the results of previous studies about discipleship, but with no new aspects having been raised.

Palatty (1987) wrote a paper on Discipleship and the Covenant ${ }^{17}$. This paper is presented too categorically. This theme would have had more credibility if the topic could have been viewed and interpreted from the Johannine communities' perspective as well ${ }^{18}$. This endeavour attempts to show that the important elements of the New Covenant promised in the Old 
Testament (Ezk 36:23-36) are realised in the new relationship established in Jesus Christ, who is the Redeemer and the Mediator of the New Covenant. According to him the Fourth Gospel has specific terminology to explain the theology of discipleship. For this purpose he considers the Johannine call narrative (Jn 1:35-51), in which the author has characteristic notions to impart regarding the theology of discipleship ${ }^{19}$. According to Palatty the call narrative is composed having specific Old Testament covenantal concepts, imagery and ideas in mind. He concentrates on showing that in Jesus the promise of the New Covenant in the Old Testament is being fulfilled in the relationship between Jesus and the disciples. While Vellanickal looked at this relation from linguistic and theological perspectives, Palatty's approach was to indicate what discipleship is from a covenantal perspective 20 .

Winbery (1988) wrote a paper, Abiding in Christ: The concept of discipleship in John ${ }^{21}$. In this paper he indicates clearly what the essential meaning of "abide" concerns and concludes that it has a theological meaning (to abide) and a non-theological meaning (to stay or to remain). His interest in this article is in the theological meaning of discipleship in the Fourth Gospel22. His goal is to indicate that the disciples' relationship with Jesus never obtained the perfection of that between God and Jesus, but the relationship was seen as being similar to that relationship and patterned on $\mathrm{it}^{23}$. This is also the conclusion to which he came. Unfortunately, Winbery was not successful in keeping to his subject in his exegesis. He did not devote enough attention to this subject and to the four important chapters on discipleship in the Last Discourse (chs 14-17)24.

According to Du Rand ${ }^{25}$, Johannine discipleship goes hand in hand with perspectives on the Johannine community. Therefore he incorporates the narratological function of the Farewell Discourses to cast light on Johannine discipleship. Du Rand correctly refers to the fact that in order to elaborate on these perspectives, the exegete is compelled to obtain further information on discipleship from extra-textual data. According to him a Johannine disciple is particularly characterised by belief, knowledge and love.

From a sociological perspective the Johannine community finds its identity through a view on discipleship, implemented by the "new" commandment and the Paraclete as manifested in the Beloved Disciple. According to Du Rand, "The Johannine narrative contributes to this sense of identification by telling the story from a retrospective ideological view of transparency, concentrating on two lines, the Jesus-ministry and the disciple-ministry. The result is identification between reader and 
discipleship which leads to definite self definition of discipleship as the appropriation of realized eschatological salvation". The value of this article by Du Rand is that it stimulates the mind to consider new horizons on the research of the concept of discipleship in the Fourth Gospel.

\subsection{Monographs:}

According to my investigation only a few monographs have been written about this theme. Schultz (1962) in his Nachfolgen und Nachahmen ${ }^{26}$ considers the Fourth Gospel specifically in two sections of his monograph. In the development of the concept, he indicates that the pupil of the historical Jesus became the disciple of the exalted Lord, a member of the Christian community. The typical characteristic of a Johannine disciple is faith in the Messiahship of Jesus and his son ship with God in a community of life. For the outsider discipleship becomes visible in the mutual aspect of the life of the community. Schultz concludes that the community's destiny is suffering on account of its association with Jesus and not with the world. In another section Schultz states that the Fourth Evangelist was concerned with the basic relationship of the disciple to the Revealer. Believing is the essential link for the one who desired to follow Jesus. Finally, Schultz returns to the distinctive notion of "following" in its Johannine development of withdrawal from the world and community with God through faith in Christ.

The next monograph followed ten years later when Jiménez (1972) wrote his extensive study on discipleship in the Fourth Gospel ${ }^{27}$. According to Pazdan ${ }^{28}$, Jiménez based his investigation on a three part study: Part one concerns a survey on the significance of the term $\mu \alpha \theta \eta \tau \grave{\eta} \varsigma$ in the literature previous to the Fourth Gospel, i e, Greek, Rabbinic, LXX, Synoptics and Acts. In part two he based the theological meaning of $\mu \alpha \theta \eta \tau \dot{\eta} \varsigma$ on a threefold perspective: a) material use; b) formal significance; c) the Beloved Disciple as the embodiment of the term. In part three of his study Jiménez presents the theological-trinitarian projection of the concept "disciple of Jesus" in three sections. The first section treats the relationship of the disciple with the Father. The second section deals with the relationship of the disciple to Jesus which is developed through a discussion of the Good Shepherd parable and the names given to the disciples in the second half of the Gospel. The third section is concerned with the relationship of the disciples with the Holy Spirit as indicated in the Last Discourse. Jiménez concludes this section by reasserting the disciples' relationship with the triune God. Siker-Gieseler ${ }^{29}$ indicated that unfortunately Jiménez, seems to be too concerned with describing the ideal disciple of Jesus. This third part 
of his study is also seriously hampered by his attempt to show how discipleship explicitly reflects the activity of the trinity.

The 80's indicate a new era of interest in discipleship in the Fourth Gospel. The third monograph appeared in this decade and was a thesis by Pazdan (1982) ${ }^{30}$. In the first of the five chapters Pazdan tries to indicate how the literature of the present century has responded to the understanding of $\mu \alpha \theta \eta \tau \dot{\eta} \varsigma$ and the Fourth Gospel. Chapters two (79 pages), three (81 pages) and four (70 pages) form a trilogy. During the scholar's investigation she discovered six pairs of verbs which appear in a particular

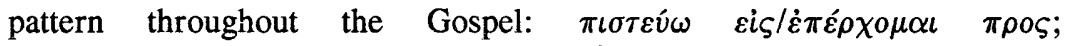
oi $\delta \alpha / \gamma \iota \gamma \nu \omega ́ \sigma \kappa \omega ; \quad \dot{\alpha} \gamma \alpha \pi \dot{\alpha} \omega / \phi \iota \lambda \hat{\varepsilon} \omega ; \quad \mu \dot{\varepsilon} \nu \omega \quad \dot{\varepsilon} \nu / \varepsilon i \sigma \alpha \iota \quad \dot{\varepsilon} \nu ; \quad \dot{\alpha} \kappa o v ́ \omega / \tau \eta \rho \dot{\varepsilon} \omega ;$ $\zeta \eta \tau \varepsilon \dot{\varepsilon} \omega / \varepsilon \dot{v} \rho i \sigma \kappa \omega$. She wrote that it had became apparent that the context for

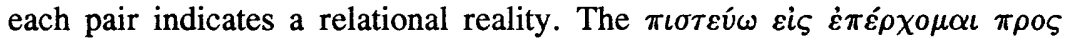
states the relationship of the believers to Jesus (Chapter two: "The Basis for Discipleship - Believing in Jesus"). The oi $\delta \alpha / \gamma \iota \gamma \nu \omega \sigma \kappa \omega$; $\dot{\alpha} \gamma \alpha \pi \dot{\alpha} \omega / \phi \iota \lambda \dot{\varepsilon} \omega ; \mu \varepsilon \dot{\nu} \omega \dot{\varepsilon} \nu / \varepsilon i \nu \alpha \iota \dot{\varepsilon} \nu$ express a mutuality of relationships between Jesus and the disciples and less frequently between the Father and the disciples (Chapter three: "The heart of discipleship - Mutuality of

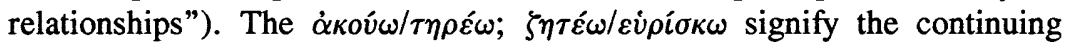
task of the disciples which foster the above relationships with Jesus (Chapter four: "The Tasks of Discipleship - Hearing and keeping Jesus' word; seeking and finding Him").

In her conclusion ${ }^{31}$ Pazdan states that these six pairs of verbs point to the reality of discipleship. They suggest a theological synthesis based on the relational nature of discipleship which constitutes the selfdefinition and function of the Johannine community ${ }^{32}$. For Pazdan discipleship in the Fourth Gospel is the appropriation of salvation.

In the successive year C A Ray (1983) ${ }^{33}$ investigates the possible backgrounds of the $\delta \imath \delta \alpha \sigma \sigma \alpha \lambda \varsigma^{\prime} / \mu \alpha \theta \eta \tau \grave{\eta} \varsigma$ relationship and an analysis of the Johannine concept of discipleship by means of an examination of the literature produced by the Johannine school. Chapter one of this thesis is a composition of the existence and history of the Johannine school. Ray tried to sketch the broad lines of development which are generally accepted by Johannine scholars. Chapter two of this thesis is an investigation of the $\delta\llcorner\delta \dot{\alpha} \sigma \kappa \alpha \lambda o \varsigma / \mu \alpha \theta \eta \tau \dot{\eta} \varsigma$ relationship prior to and contemporary with the Fourth Gospel. The third chapter is a study of the titles used by the Fourth Evangelist for a disciple in the Fourth Gospel. Chapter four is an etymological and contextual study of words used by the Fourth Evangelist to describe a disciple. The final part comprises the conclusions of the investigation. An attempt is made to analyze, evaluate and arrange the 
material in such a way as to give a logical and complete explanation of the concept of discipleship in the Johannine school. The historical-critical method of research is the primary method employed. This study is not a trustworthy analysis of Ray's objective and the exegetical work is also disappointing. It seems as if his exegesis is subordinate to his theologicphilosophical understanding of discipleship. The conclusion contains no new and fresh aspects.

The next monograph is a dissertation by L M Neethling (1984) ${ }^{34}$. In this study $\mu \alpha \theta \eta \tau \dot{\eta} \varsigma$ and related terms have been investigated in texts which, according to him, are relevant to or can be connected with discipleship ${ }^{35}$. He worked on the basis of discourse analysis and in the concluding chapter systematizes his conclusions. After reading this dissertation one cannot help but to ask whether the author has not been too hasty dismissing his exegesis (as in the case of Ray) in favour of theological opinions which favour the author's subjective viewpoint. He makes conclusions and new statements in his last chapter which he has failed to argue in his exegesis. Neethling's attempt to build this dissertation on discourse analysis alone is its basic weakness. This flaw appears throughout the work. No new insights are made and also his exegesis is disappointing ${ }^{36}$. According to his title (as in the case of Ray), this study is also incomplete for in his summary he only refers to the characteristics and primary requirements for discipleship namely Love.

The last considered monograph is the one of D F Tolmie (1992)37. The purpose of the study is to conduct a detailed analysis of John 13:117:26 in terms of a narratological framework. Tolmie detected two important developments from these chapters concerning discipleship: "Firstly, the paradigm of traits associated with the disciples is supplemented by a number of traits indicating what discipleship should look like, and secondly, the benefits of true discipleship are stressed". Based on the way in which the different narratological facets are handled in chapters 13-17, it is clear that one of the objectives the implied author aims to achieve is to provide the implied reader with a comprehensive ideological perspective on discipleship. According to him this perspective on discipleship has already been introduced on several occasions in the first half (chs 1-12) of the Fourth Gospel. In chapters 13-17 it is much more extensively developed and as such represents an important develop-ment: "The ideological perspective on discipleship is conveyed in several ways, for example by means of the underlying deep structure, the way in which the surface structure between events is developed, the various ways in which the disciples are characterised and the ideological facet of focalisation". 
This is a valuable study on discipleship in the Fourth Gospel, but unfortunately with little theological discussion owing to the objective of the study.

\subsection{Commentaries:}

A number of commentaries ${ }^{38}$ have been examined according to some relevant texts ${ }^{39}$ concerning discipleship; $\mu \alpha \theta \eta \tau \dot{\eta} \varsigma$ and $\dot{\alpha} \kappa o \lambda о v ́ \theta \varepsilon \omega$ regularly occur as well as the metaphor in 15:1-8 and the prayer in 17:1-26. Of all the commentaries consulted, only Schnackenburg ${ }^{40}$ gives an extended explanation of discipleship.

The commentary of Bultmann is the only other commentary which incorporates frequent references to discipleship in the exegesis and discussion of the text. In 13:36-14:4 Bultmann ${ }^{41}$ discusses "The promise of discipleship" which relates to the rest of chapter 14. In his discussion of the Johannine vocabulary in Appendix I, Brown ${ }^{42}$ discusses words relevant to discipleship: $\dot{\alpha} \gamma \dot{\alpha} \pi \eta, \dot{\alpha} \lambda \dot{\eta} \theta \varepsilon \iota \alpha, \mu \varepsilon \nu \varepsilon \iota \nu, \pi \iota \sigma \tau \varepsilon \dot{v} \varepsilon \iota \nu, \dot{\varepsilon} \nu \tau o \lambda \dot{\eta}$. etcetera, but unfortunately not $\mu \alpha \theta \eta \tau \dot{\eta} \varsigma$ or $\dot{\alpha} \kappa o \lambda o v \theta \varepsilon \varepsilon \omega$. In $1: 35 \mathrm{ff}$ he refers to discipleship in his exegetical exposition, but does not discuss it here or in other texts in which it is relevant. Although Brown writes in his book The community of the beloved disciple that "discipleship is the primary Christian category for John", he never really develops this in any of his extensive studies.

Morris $^{43}$ also discusses important themes central to the Fourth Gospel in addenda, but never touches on discipleship. Fewer references in connection with discipleship occur sporadically in his exegetical material than in Bultmann. In general most commentaries in their exegetical discussions of texts incorporate or occasionally refer to discipleship.

\subsection{Theologies:}

In the theologies consulted no definite attention has been paid to discipleship although certain aspects $^{44}$ have been dealt with. Most theologies ${ }^{45}$ respect the different main characteristics of each Gospel and therefore treat it accordingly. Although Morris respects the individuality of each Gospel's theology, he pays attention to discipleship in the Gospel of Luke but ignores it in the Gospel of John. Thus the different theologies offer no definite contribution to the concept of discipleship.

\subsection{Theological Dictionaries and Encyclopedias:}

Under the headings disciple, discipleship and $\mu \alpha \theta \eta \tau \dot{\eta} \varsigma$ the concept of discipleship has been treated, but in some dictionaries and encyclopedias is 
not even mentioned. In all these works no differentiation and respect of the individuality of each Gospel receives preference. Almost the same information about discipleship occurs throughout, namely: statistics, meaning, some characteristics, background, relation to the Greek world and Rabbinic realm and other groups of disciples. In most cases the content used is vague, general and concise. Only in the Dictionary of the New Testament ${ }^{46}$ the different words for being a disciple have been explained with respect to the individuality and distinctiveness of each Gospel. Only two paragraphs have been dedicated to discipleship in the Fourth Gospel ${ }^{47}$. The Theologisches Wörterbuch zum Neuen Testament ${ }^{48}$ is the most extensive on this subject and approaches the disciples in the Gospels and Acts collectively through a word study. According to him $\mu \alpha \theta \eta \tau \eta े$ implies the existence of a personal attachment to Jesus which shapes the whole life of the disciple. Rengstorf does not develop the distinctiveness of any Gospel's portrayal of the disciples ${ }^{49}$. He is helpful in pointing out the differences between the $\mu \alpha \theta \eta \tau \alpha \grave{i}$ of Jesus and the $\mu \alpha \theta \eta \tau \alpha i$ of the philosophers and the talmud of the rabbis, stressing that the disciples of Jesus were committed to his person, whereas the disciples of the philosophers and rabbis were committed to their teachings. He also develops the concepts of the obedience of the disciples, their obligation to suffer, their role as witnesses, and the initiative of Jesus behind the disciples, which are common themes to all four Gospels. He offers two conclusions in summary of his findings: (1) The disciples were moulded by their self-awareness of Jesus; Jesus is for them their Lord, not the rabbi; and (2) the task to which they are called as his disciples is witnessing to Jesus, which testimony is based on the personal relationship of the disciples with Jesus.

In conclusion, although Rengstorf provides an extensive study of $\mu \alpha \theta \eta \tau \grave{\eta} \varsigma$ in the Gospels and Acts as a whole, he does not really develop the Fourth Gospel's distinctive portrayal of the disciples. Just as the study of Bultmann can be criticized for presenting discipleship in the Fourth Gospel, but neglecting the disciples, on the other hand, Rengstorf's word study can be faulted for dealing extensively with the disciples, but neglecting the larger theme of discipleship in the Fourth Gospel ${ }^{50}$. For many years the contribution of Rengstorf on discipleship was regarded as one of the leading analyses on the topic. 


\section{CONCLUSIONS}

\subsection{Possible reasons for the relative lack of interest in discipleship in the Fourth Gospel}

In the first seven decades of this century there was relatively little interest

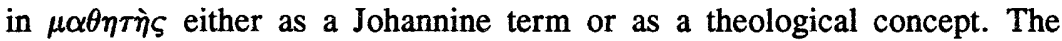
literature consulted is sketchy about discipleship in the Fourth Gospel. Research on this concept has been limited to articles, a few monographs and references in writings which do not deal specifically with discipleship and only aspects of discipleship are adressed. According to Kysar ${ }^{51}$, until 1975, when he wrote The Fourth Evangelist and his Gospel, there had not been any explicit interest in the concept of discipleship in the Fourth Gospel. Thus by this time discipleship has not been rationalized by a comprehensive approach and study. The first substantial approach to research about discipleship in the Fourth Gospel came in 1972 when Jiménez wrote his El discipulo de Jesucristo segun el evangelio de S Juan. In the 80's greater interest followed.

The increased interest in this subject in the 80's is due to Rudolph Bultmann. In his book Understanding the Fourth Gospel Ashton ${ }^{52}$ indicates the shift of interest in the different trends of research in the Fourth Gospel which have taken place. According to him the contribution of Rudolf Bultmann constitutes a watershed in the history of Johannine scholarship. The gap which Bultmann caused by virtually ignoring one particular area ${ }^{53}$ of enquiry has marked the most significant advance in Johannine studies in the latter half of the twentieth century ${ }^{54}$.

Some factors then which could contribute to this lack of interest are: (1) The major theological focus in the Gospel has been christological and eschatological55; (2) There has been renewed concern about the sources for the Gospel; (3) There has been a growing interest in the community of believers; (4) In the 60's, 70's and 80's articles and monographs addressed the identity and development of the Johannine community(ies) and its self understanding; (5) Interest in the Johannine community determined the ecclesiological investigations and led to major contributions about the Johannine school ${ }^{56}$.

This clearly shows why there was not much interest in discipleship on account of other topics which dominated the scene. After Bultmann, as has been seen, more attention was paid to the situation and the circumstances of the audience 57 , which definitely contributes to a greater interest on discipleship and ecclesiology in the Fourth Gospel. 


\subsection{General observations}

In general the literature can be distinguished according to topical interest and methodology. The literature of the present century on $\mu \alpha \theta \eta \tau \eta े$ indicates three periods of methodology. Firstly, from 1900-1971 a thematic-theological approach highlighted some characteristics of discipleship as they appeared in all four Gospels, Acts and with some mention of the concept in the Pauline literature. Secondly, Jiménez caused a paradigm shift with his major contribution to restrict his study to discipleship to only the Fourth Gospel. Thirdly, in the 70's, 80's and 90's exegetical methods such as the historic-critical, discourse analysis and narratological methods were used to come to an understanding of the function of the disciples and the meaning of discipleship in the different Gospels.

Since the 70 's a few important contributions have been made on discipleship in the Fourth Gospel58. Such contributions increased through the 80's although some of the experts ${ }^{59}$ on the Fourth Gospel did not deal with this topic.

Although no constant current of influence on discipleship in the Fourth Gospel throughout the different decades has been observed, most scholars are unanimous that the focal point of discipleship in the Fourth Gospel lies in the "Last Discourses"60.

There was a constant theological onslaught even when different exegetical methods were used (i.e. Vellanickal, Siker-Gieseler, Neethling, Doohan to name a few). The limited research undertaken did not provide many new insights, but highlighted certain aspects.

\section{NOTES:}

1 See D G van der Merwe, Discipleship in the Fourth Gospel (Unpublished D.D. dissertation), University of Pretoria 1995.

2 The discussion of discipleship in a chapter of a book will also be considered here.

3 Consult M M Pazdan, Discipleship as the appropriation of eschatological salvation in the Fourth Gospel, Michigan 1982 for an overview about works on discipleship in the Gospels from the 1950's.

4 E Schweizer, Erniedrigung und Erhöhung bei Jesus und seinen Nachfolgern, Zurich 1962. 
5 See Van der Merwe, op cit, 1995, 10.

6 B Rigaux, “Die Jünger Jesu in Johannes 17", Theologische Quartalschrift 150 (1970), 202-213.

7 R A Culpepper, The Johannine School: An evaluation of the Johannine-School hypothesis based on an investigation of the nature of ancient schools (Society of biblical Literature Dissertation Series 26), Missoula 1975, 272; compare J A du Rand, Perspectives on Johannine Discipleship according to the Farewell Discourses, Neotestamentica 25/2 (1991), 313.

8 R Schnackenburg, Das Johannesevangelium (III Teil), Kommentar zu Kap. 1321, Freiburg 1975.

9 Schnackenburg, op cit, $234 \mathrm{f}$.

$10 \mathrm{M}$ de Jonge, Jesus: Stranger from heaven and Son of God. Jesus Christ and the Christians in Johannine perspective, Missoula 1977.

11 J S Siker-Gieseler, "Disciples and discipleship in the Fourth Gospel: A canonical approach", Studia Biblica et Theologica 10 (1980), 199-227.

12 Compare also the work of $\mathrm{R} \mathrm{M}$ Jiménez, El discípulo de Jesucristo, según el evangelio se S. Juan, Granada 1972.

13 A S J Dulles, “Discipleship”, in: M Eliade (ed), The Encyclopedia of Religion (Vol IV), New York 1987, 362; M M Pazdan, "Nicodemus and the Samaritan woman: contrasting models of discipleship", Biblical Theology Bulletin 17 (1987), 145f; L Doohan, John. Gospel for a new age, Santa Fe, New Mexico 1988, 136f,

14 M Vellanickal, "Discipleship' according to the Gospel of John", Jeevadhara 10/56 (1980), 131-147.

15 R E Brown, The churches the apostles left behind, London 1984.

16 F F Segovia, "Peace I give with you; My peace I give to you: Discipleship in the Fourth Gospel", in: F F Segovia, Discipleship in the New Testament, Philadelphia 1985.

17 P Palatty, "Discipleship and the covenant", Bible Bhashyam 13/3 (1987), 199227. Compare D G van der Merwe, op cit, 1995, 13 on how Palatty was probably influenced by other scholars.

18 J L Martyn, History and theology in the Fourth Gospel, New York 1968 put forward a thesis which interprets the Fourth Gospel as a drama presented at two 
levels, one of which concerns Jesus and the other which concerns the community of the evangelist in which the tradition of Jesus was shaped.

19 Compare with Vellanickal, op cit, 1980, 131-147.

20 In reverse J W Pryor, "Covenant and community", Reformed Theological Review 47/2 (1988), 44-51, tries to prove that the Johannine community is not sectarian, but covenantal. He approaches the attainment of this goal by using terminology which is normally used to describe discipleship: $\dot{o}$ ioıo, Vine branches, Flock-Shepherd, Keeping-Abiding-Loving (Jn 15:1-7).

21 C L Winbery, “Abiding in Christ: Concept of discipleship”, Theological Educator 38 (1988), 104-120.

22 This is a lexicographical explanation which is always vague. Words have meaning primarily in context. See J $\mathbf{P}$ Louw, Semantiek van Nuwe Testamentiese Grieks, Pretoria 1976.

23 According to him this is evident in the great discipleship chapters on which he did some exegesis.

24 He uses sources sparingly and does not refer to the best commentaries on the Fourth Gospel such as Schnackenburg, Brown, Lindars, Bultmann, Barrett, Morris etcetera.

25 J A du Rand, op cit, 311-325.

26 A Schultz, Nachfolgen und Nachahmen: Studien "Über" das Verhältnis der neutestamentlichen Jüngerschaft zur urchristlichen Vorbildethik, Kösel 1962.

27 Jiménez, op cit, 1972.

28 Pazdan, op cit, 1982, 33.

29 Siker-Gieseler, op cit, 1980, 206.

$30 \quad$ Pazdan, op cit, 1982.

$31 \quad$ Pazdan, op cit, 307.

32 E Käsemann, The Testament of Jesus. A study of the Gospel of John in the light of chapter 17 (Translated by G Krodel), London 1968.

33 C A Ray, The concept of discipleship in the Johannine School, New Orleans 1983. 
34 L M Neethling, Dissipelskap in die Johannesevangelie: 'n ondersoek rondom die begrip en verwante begrippe in die Johannesevangelie (Ongepubliseerde $\mathrm{BD}$ skripsie), Pretoria 1984.

35 John $1: 35-51 ; 2: 1-12 ; 4: 1-38 ; 6: 1-21 ; 6: 60-71 ; 7: 1-9 ; 8: 31-32 ; 13: 1-36 ; 14: 1-$ $31 ; 15: 1-17 ; 20: 19-23 ; 21: 15-19$.

36 He undertook a discourse analysis but did not succeed in explaining this analysis in terms of linguistic, semantic and theological explanation.

37 D F Tolmie, John 13:1-17:26 in narratological perspective, (Unpublished D.Th dissertation), Bloemfontein 1992.

$38 \quad$ See Van der Merwe, op cit, 1995, 18.

$39 \quad 1: 35-51 ; 6: 60-71 ; 8: 31 ; 12: 26 ; 13: 1 \mathrm{ff} ; 14: 1-16: 33$.

$40 \quad$ Schnackenburg, op cit, 1975; 231-245.

41 R Bultmann, Das Evangelium des Johannes, Göttingen ${ }^{11} 1950$.

42 R E Brown, The Gospel according to John (I-XII), London 1975, 498.

43 L Morris, The Gospel according to John, Grand Rapids 1971.

44 Characteristics such as: Love, Faith, Abiding in.

45 See Van der Merwe, op cit, 1995, 19.

46 D Müller, “Apostle”, in: C Brown (ed), DNTT (Vol 1), Exeter 1975.

47 Müller, op cit, 483, 490.

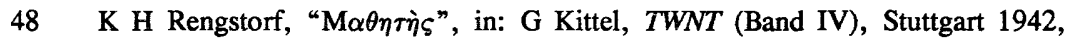
444-464.

49 Rengstorf, op cit, 1942 does mention a few elements of discipleship which are more distinctive in the Fourth Gospel than in the other Gospels.

50 Compare Siker-Gieseler, op cit, 1980.

$51 \quad$ R Kysar, The Fourth Evangelist and His Gospel, Minneapolis 1975.

52 J Ashton, Understanding the Fourth Gospel, Oxford 1991.

53 According to my judgement Ashton, op cit, 1991, 44) refers to the Ecclesiology. 
$54 \quad$ Van der Merwe, op cit, 1995, 20.

55 Nevertheless, discipleship has a strong christological point of departure.

56 Pazdan, op cit, 1982, 41f; Segovia, op cit, 1985, 77; J McPolin, "Studies in the Fourth Gospel", Irish Biblical Studies 2 (1980), 3-26.

57 See Van der Merwe, op cit, 1995, 21.

58 Rigaux, op cit, 1970; Jiménez, op cit, 1972; Schnackenburg, op cit, 1975; De Jonge, op cit, 1977.

59 See Van der Merwe, op cit, 1995, 21.

60 Du Rand, op cit, 1991; Hartin, op cit, 1991; Winbury, op cit, 1988; Pazdan, op cit, 1982; Rigaux, op cit, 1970; Jiménez, op cit, 1972; Tolmie, op cit, 1992. 